\title{
Biofertilizers function as key player in sustainable agriculture by improving soil fertility, plant tolerance and crop productivity
}

\author{
Deepak Bhardwaj ${ }^{\dagger}$, Mohammad Wahid Ansari ${ }^{\dagger}$, Ranjan Kumar Sahoo and Narendra Tuteja
}

\begin{abstract}
Current soil management strategies are mainly dependent on inorganic chemical-based fertilizers, which caused a serious threat to human health and environment. The exploitation of beneficial microbes as a biofertilizer has become paramount importance in agriculture sector for their potential role in food safety and sustainable crop production. The eco-friendly approaches inspire a wide range of application of plant growth promoting rhizobacteria (PGPRs), endo- and ectomycorrhizal fungi, cyanobacteria and many other useful microscopic organisms led to improved nutrient uptake, plant growth and plant tolerance to abiotic and biotic stress. The present review highlighted biofertilizers mediated crops functional traits such as plant growth and productivity, nutrient profile, plant defense and protection with special emphasis to its function to trigger various growth- and defense-related genes in signaling network of cellular pathways to cause cellular response and thereby crop improvement. The knowledge gained from the literature appraised herein will help us to understand the physiological bases of biofertlizers towards sustainable agriculture in reducing problems associated with the use of chemicals fertilizers.
\end{abstract}

Keywords: Biofertilizer, Crop improvement, Environmental stress, Mode of action of biofertilizers, Sustainable agriculture

\section{Introduction}

Conventional agriculture plays a significant role in meeting the food demands of a growing human population, which has also led to an increasing dependence on chemical Fertilizers and pesticides [1]. Chemical fertilizers are industrially manipulated, substances composed of known quantities of nitrogen, phosphorus and potassium, and their exploitation causes air and ground water pollution by eutrophication of water bodies [2]. In this regard, recent efforts have been channelized more towards the production of 'nutrient rich high quality food' in sustainable comportment to ensure bio-safety. The innovative view of farm production attracts the growing demand of biological based organic fertilizers exclusive of alternative to agro-chemicals [3]. In agriculture, encourage alternate means of soil fertilization relies on organic inputs to improve nutrient supply and conserve the field management

\footnotetext{
* Correspondence: narendra@icgeb.res.in

${ }^{\dagger}$ Equal contributors

Plant Molecular Biology Group, International Centre for Genetic Engineering and Biotechnology (ICGEB), Aruna Asaf Ali Marg, New Delhi 110067, India
}

[4]. Organic farming is one of such strategies that not only ensures food safety but also adds to the biodiversity of soil [5]. The additional advantages of biofertilizers include longer shelf life causing no adverse effects to ecosystem [6].

Organic farming is mostly dependent on the natural microflora of the soil which constitutes all kinds of useful bacteria and fungi including the arbuscular mycorrhiza fungi (AMF) called plant growth promoting rhizobacteria (PGPR). Biofertilizers keep the soil environment rich in all kinds of micro- and macro-nutrients via nitrogen fixation, phosphate and potassium solubalisation or mineralization, release of plant growth regulating substances, production of antibiotics and biodegradation of organic matter in the soil [7]. When biofertilizers are applied as seed or soil inoculants, they multiply and participate in nutrient cycling and benefit crop productivity [8]. In general, $60 \%$ to $90 \%$ of the total applied fertilizer is lost and the remaining $10 \%$ to $40 \%$ is taken up by plants. In this regard, microbial inoculants have paramount significance in integrated nutrient management systems to sustain agricultural productivity and healthy environment [9]. 
The PGPR or co-inoculants of PGPR and AMF can advance the nutrient use efficiency of fertilizers. A synergistic interaction of PGPR and AMF was better suited to $70 \%$ fertilizer plus AMF and PGPR for P uptake. Similar trend were also reflected in $\mathrm{N}$ uptake on a whole-tissue basis which shows that $75 \%, 80 \%$, or $90 \%$ fertilizer plus inoculants were significantly comparable to $100 \%$ fertilizer [10]. This review is intended to cater to the needs of agriculturists and plant biologists whose work focuses on creating clean and efficient means to improve the quality of soil by nourishing and maintaining the useful and natural flora of microorganisms or PGPRs. Further, it presents recent developments in the area of field management that reveals the potential application of biofertilizers and increased nutrient profiles, plant growth and productivity, and improved tolerance to environmental stress with a particular emphasis on mechanism of the feat of biofertilizers.

\section{The microbiome: potential significance of beneficial microbes in sustainable agriculture}

The rhizosphere, which is the narrow zone of soil surrounding plant roots, can comprise up to $10^{11}$ microbial cells per gram of root [11] and above 30,000 prokaryotic species [12] that in general, improve plant productivity [12]. The collective genome of rhizosphere microbial community enveloping plant roots is larger compared to that of plants and is referred as microbiome [13], whose interactions determine crop health in natural agroecosystem by providing numerous services to crop plants viz., organic matter decomposition, nutrient acquisition, water absorption, nutrient recycling, weed control and bio-control [14]. The metagenomic study provides the individual the core rhizosphere and endophytic microbiomes activity in Arabidopsis thaliana using 454 sequencing (Roche) of $16 \mathrm{~S}$ rRNA gene amplicons [15]. It has been proposed that exploiting tailor-made core microbiome transfer therapy in agriculture can be a potential approach in managing plant diseases for different crops [16]. Rhizosphere microbial communities an alternative for chemical fertilizers has become a subject of great interest in sustainable agriculture and bio-safety programme.

A major focus in the coming decades would be on safe and eco-friendly methods by exploiting the beneficial micro-organisms in sustainable crop production [17]. Such microorganisms, in general, consist of diverse naturally occurring microbes whose inoculation to the soil ecosystem advances soil physicochemical properties, soil microbes biodiversity, soil health, plant growth and development and crop productivity [18]. The agriculturally useful microbial populations cover plant growth promoting rhizobacteria, $\mathrm{N}_{2}$-fixing cyanobacteria, mycorrhiza, plant disease suppressive beneficial bacteria, stress tolerance endophytes and bio-degrading microbes [8]. Biofertilizers are a supplementary component to soil and crop management traditions viz., crop rotation, organic adjustments, tillage maintenance, recycling of crop residue, soil fertility renovation and the biocontrol of pathogens and insect pests, which operation can significantly be useful in maintaining the sustainability of various crop productions [19]. Azotobacter, Azospirillum, Rhizobium, cyanobacteria, phosphorus and potassium solubilising microorganisms and mycorrhizae are some of the PGPRs that were found to increase in the soil under no tillage or minimum tillage treatment [20,21]. Efficient strains of Azotobacter, Azospirillum, Phosphobacter and Rhizobacter can provide significant amount of nitrogen to Helianthus annus and to increase the plant height, number of leaves, stem diameter percentage of seed filling and seed dry weight [22]. Similarly, in rice, addition of Azotobacter, Azospirillum and Rhizobium promotes the physiology and improves the root morphology [23].

Azotobacter plays an important role in the nitrogen cycle in nature as it possesses a variety of metabolic functions [18]. Besides playing role in nitrogen fixation, Azotobacter has the capacity to produce vitamins such as thiamine and riboflavin [24], and plant hormones viz., indole acetic acid (IAA), gibberellins (GA) and cytokinins (CK) [25]. A. chroococcum improves the plant growth by enhancing seed germination and advancing the root architecture [26] by inhibiting pathogenic microorganisms around the root systems of crop plants [27]. This genus includes diverse species, namely, $A$. chroococcum, A.vinelandii, A. beijerinckii, A. nigricans, $A$. armeniacus and $A$. paspali. It is used as a biofertilizer for different crops viz., wheat, oat, barley mustard, seasum, rice, linseeds, sunflower, castor, maize, sorghum, cotton, jute, sugar beets, tobacco, tea, coffee, rubber and coconuts [28]. Azospirillum is another free-living, motile, gram variable and aerobic bacterium that can thrive in flooded conditions [6] and promotes various aspects of plant growth and development [29]. Azospirillum was shown to exert beneficial effects on plant growth and crop yields both in greenhouse and in field trials [30]. Diverse species of the genus Azospirillum including $A$. lipoferum, A. brasilense, A. amazonense, A. halopraeferens and $A$. irakense have been reported to improve productivity of various crops [6]. Interestingly, it was observed that Azospirillum inoculation can change the root morphology via producing plant growth regulating substances [31] via siderophore production [6]. It also increases the number of lateral roots and enhances root hairs formation to provide more root surface area to absorb sufficient nutrients [32]. This improves the water status of plant and aids the nutrient profile in the advancement of plant growth and development [33,34]. Co-inoculation of Azospirillium brasilense and Rhizobium meliloti plus 2,4D posed positive 
effect on grain yield and N,P,K content of Triticum aestivum [35]. Rhizobium has been used as an efficient nitrogen fixer for many years. It plays an important role in increasing yield by converting atmospheric nitrogen into usable forms [36]. Being resistant to different temperature ranges Rhizobium normally enters the root hairs, multiplies there and forms nodules [37]. Rhizobium inoculants in different locations and soil types were reported to significantly increase the grain yields of bengal gram [38], lentil [39], pea, alfalfa and sugar beet rhizosphere [40], berseem [41], ground nut [36] and soybean [42]. These Rhizobium isolates obtained from wild rice have been reported to supply nitrogen to the rice plant to promote growth and development [43]. One of the species of Rhizobium, Sinorhizobium meliloti 1021 infects plants other than leguminous plants like rice to promote growth by enhancing endogenous level of plant hormone and photosynthesis performance to confer plant tolerance to stress [44]. In groundnut, IRC-6 strain of Rhizobium has resulted in the enhancement of several useful traits such as increased number of pink coloured nodules, nitrate reductase activity and leghaemoglobin content in 50 DAI (days after inoculation) [36]. Rhizobial symbiosis provides defence to plants against pathogens and herbivores, such as example, Mexican bean beetle [45] and the green house whitefy Trialeurodes vaporariorum [46] (Figure 1).

\section{Biofertlizers exploitation and nutrients profile of crops}

A key advantage of beneficial microorganisms is to assimilate phosphorus for their own requirement, which in turn available as its soluble form in sufficient quantities in soil. Pseudomonas, Bacillus, Micrococcus, Flavobacterium, Fusarium, Sclerotium, Aspergillus and Penicillium have been reported to be active in the solubilisation process [47]. A phosphate-solubilizing bacterial strain NII-0909 of Micrococcus sp. has polyvalent properties including phosphate solubilisation and siderophore production [48]. Similarly, two fungi Aspergillus fumigatus and $A$. Niger were isolated from decaying cassava peels were found to convert cassava wastes by the semi-solid fermentation technique to phosphate biofertilizers [49]. Burkholderia vietnamiensis, stress tolerant bacteria, produces gluconic and 2-ketogluconic acids, which involved in phosphate solubilisation [50]. Enterobacter and Burkholderia that were isolated from the rhizosphere of sunflower were found to produce siderophores and indolic compounds (ICs) which can solubilize phosphate [51]. Potassium solubilising microorganisms (KSM) such as genus Aspergillus, Bacillus and Clostridium are found to be efficient in potassium solubilisation in the soil and mobilize in different crops [52]. Mycorrhizal mutualistic symbiosis with plant roots satisfies the plant nutrients demand [53], which leads to enhance plant growth and development, and protect plants from pathogens attack and environmental stress

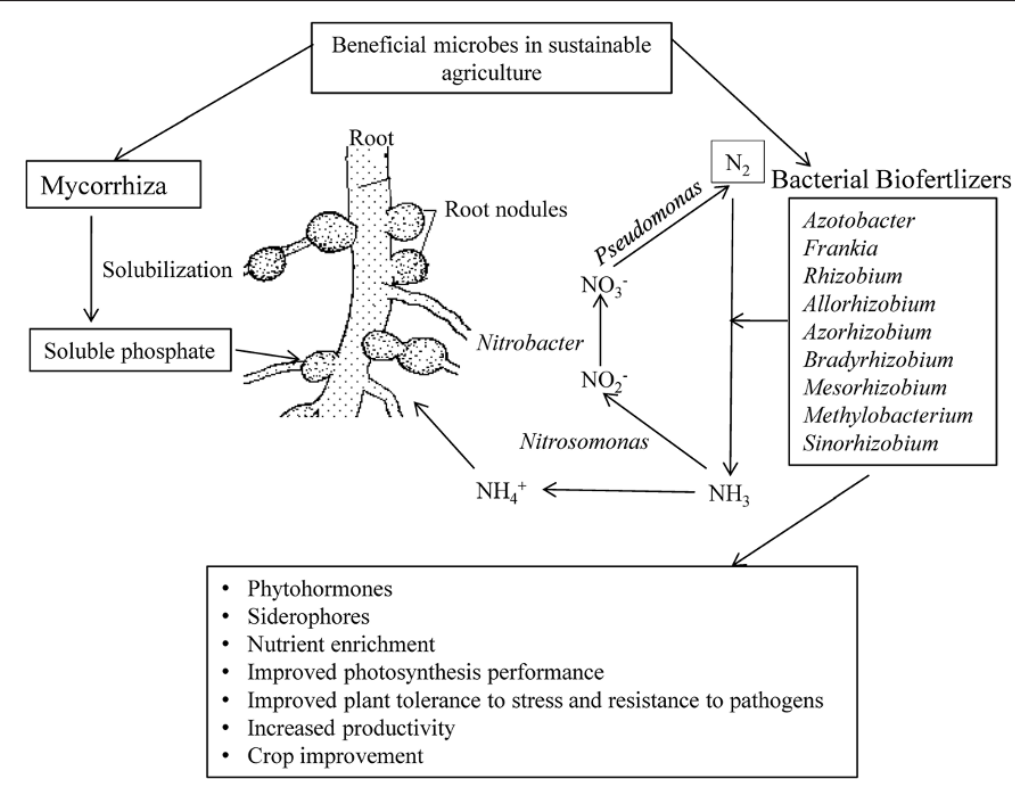

Figure 1 Potential use of soil microbes in sustainable crop production. The beneficial soil micro-organisms sustain crop production either as biofertilizers [19] or symbiont [17]. They perform nutrient solubilisation which facilitate nutrient availability and thereby uptake [20,21]. It improves the plant growth by advancing the root architecture [26]. Their activity provides several useful traits to plants such as increased root hairs, nodules and nitrate reductase activity and [36]. Efficient strains of Azotobacter, Azospirillum, Phosphobacter and Rhizobacter can provide significant amount of available nitrogen through nitrogen cycling [22]. The biofertilizers produced plant hormones, which include indole acetic acid (IAA), gibberellins $(\mathrm{GA})$ and cytokinins (CK) $[25,44]$. Biofertilizers improve photosynthesis performance to confer plant tolerance to stress [44] and increase resistance to pathogens [45] thereby resulting in crop improvement [18]. 
[54]. It leads to the absorption of phosphate by the hyphae from outside to internal cortical mycelia, which finally transfer phosphate to the cortical root cells [55]. Nitrogen fixing cyanobacteria such as Aulosira, Tolypothrix, Scytonema, Nostoc, Anabaena and Plectonema are commonly used as biofertilizers [56,57]. Besides the contribution of nitrogen, growth-promoting substances and vitamins liberated by these algae Cylindrospermum musicola increase the root growth and yield of rice plants [58]. Interestingly, genetic engineering was used to improve the nitrogen fixing potential of Anabaena sp. strain PCC7120 [59]. Constitutive expression of the het $R$ gene driven by a light-inducible promoter enhanced HetR protein expression, leading to higher nitrogenase activity in Anabaena sp. strain PCC7120 as compared with the wild-type strain. This in turn caused better growth of paddy when applied to the fields [60].

\section{Biofertilizers relevance and plant tolerance to environmental stress}

Abiotic and biotic stresses are the major constraints that are affecting the productivity of the crops. Many tools of modern science have been extensively applied for crop improvement under stress, of which PGPRs role as bio protectants has become paramount importance in this regard [61]. Rhizobium trifolii inoculated with Trifolium alexandrinum showed higher biomass and increased number of nodulation under salinity stress condition $[41,62]$. Pseudomonas aeruginosa has been shown to withstand biotic and abiotic stresses [63]. Paul and Nair [64] found that P. fluorescens MSP-393 produces osmolytes and salt-stress induced proteins that overcome the negative effects of salt. P. putida Rs-198 enhanced germination rate and several growth parameters viz., plant height, fresh weight and dry weight of cotton under condition of alkaline and high salt via increasing the rate of uptake of $\mathrm{K}^{+}$, $\mathrm{Mg}^{2+}$ and $\mathrm{Ca}^{2+}$, and by decreasing the absorption of $\mathrm{Na}^{+}$ [65]. Few strains of Pseudomonas conferred plant tolerance via 2,4-diacetylphloroglucinol (DAPG) [66]. Interestingly, systemic response was found to be induced against P. syringae in Arabidopsis thaliana by P. fluorescens DAPG [67]. Calcisol produced by PGPRs viz., P. alcaligenes PsA15, Bacillus polymyxa BcP26 and Mycobacterium phlei MbP18 provides tolerance to high temperatures and salinity stress [68]. It has been demonstrated that inoculation of plant with AM fungi also improves plant growth under salt stress [69]. Achromobacter piechaudii was also shown to increase the biomass of tomato and pepper plants under $172 \mathrm{mM} \mathrm{NaCl}$ and water stress [70]. Interestingly, a root endophytic fungus Piriformospora indica was found to defend host plant against salt stress [69]. In one of the studies it was found that inoculation of PGPR alone or along with AM like Glomus intraradices or G. mosseae resulted in the better nutrient uptake and improvement in normal physiological processes in Lactuca sativa under stress conditions. The same plant treated with $P$. mendocina increased shoot biomass under salt stress [71]. Mechanisms involved in osmotic stress tolerance employing transcriptomic and microscopic strategies revealed a considerable change in the transcriptome of Stenotrophomonas rhizophila DSM $14405^{\mathrm{T}}$ in response to salt stress [72]. Combination of AM fungi and $\mathrm{N}_{2}$-fixing bacteria helped the legume plants in overcoming drought stress [73]. Effect of A.brasilense along with AM can be seen in other crops such as tomato, maize and cassava [74-76]. A. brasilense and AM combination improved plant tolerance to various abiotic stresses [77]. The additive effect of Pseudomonas putida or Bacillus megaterium and AM fungi was effective in alleviating drought stress [78]. Application of Pseudomonades sp. under water stress improved the antioxidant and photosynthetic pigments in basil plants. Interestingly, combination of three bacterial species caused the highest CAT, GPX and APX activity and chlorophyll content in leaves under water stress [79]. Pseudomonas spp. was found to cause positive affect on the seedling growth and seed germination of $A$. officinalis L. under water stress [80]. Photosynthetic efficiency and the antioxidative response of rice plants subjected to drought stress were found to increase after inoculation of arbuscular mycorrhiza [81]. The beneficial effects of mycorrhizae have also been reported under both the drought and saline conditions [82]. Heavy metals such as cadmium, lead, mercury from hospital and factory waste accumulate in the soil and enter plants through roots [83]. Azospirillium spp, Phosphobacteria spp and Glucanacetobacter spp. isolated from rhizosphere of rice field and mangroves were found to be more tolerant to heavy metal specially iron $[83,84]$. P. potida strain 11 (P.p.11), P. potida strain 4 (P.p.4) and P. fluorescens strain 169 (P. f.169) can protect canola and barley plants from the inhibitory effects of cadmium via IAA, siderophore and 1aminocyclopropane-1-carboxylate deaminase (ACCD) [85]. It was reported that rhizoremediation of petroleum contaminated soil can be expedited by adding microbes in the form of effective microbial agent (EMA) to the different plant species such as cotton, ryegrass, tall fescue, and alfalfa [86].

PGPRs as biological agents proved to be one of the alternatives of chemical agents to provide resistance to against various pathogen attacks [87]. Apart from acting as growth-promoting agents they can provide resistance against pathogens by producing metabolites [88]. Bacillus subtilis GBO3 can induce defense-related pathways viz., salicylic acid (SA) and jasmonic acid (JA) [89]. Application of PGPR isolates viz., B. amyloliquefaciens 937b and $B$. pumilus SE-34 provide immunity against tomato mottle virus [90]. B. megaterium IISRBP 17, characterized from stem of black pepper, acts against Phytophthor 
capsici [91]. Bacillus subtilis N11 along with mature composts was found to control Fusarium infestation on banana roots [92]. Similarly, B. subtilis (UFLA285) was found to provide resistance against $R$. solani and also it induced foliar and root growth in cotton plants [93]. In another interesting study Paenibacillus polymyxa SQR21 was identified as a potential agent for the bio-control of Fusarium wilt in watermelon [94]. Further, the exploitation of PGPRs was found to be effective to manage the spotted wilt viruses in tomato [87], cucumber mosaic virus of tomato and pepper [90], and banana bunchy top virus in banana [95]. In some cases it was shown that along with bacteria, mycorrhizae can also confer resistant against fungal pathogens and inhibit the growth of many root pathogens such as $R$. solani, Pythium spp., $F$. Oxysporum, A. obscura and $H$. annosum $[96,97]$ by improving plant nutrients profile and thereby productivity [69]. For instance Glomus mosseae was effective against Fusarium oxysporum f. sp. Basilica which causes root-rot disease of basil plants [98]. Medicago tranculata also showed induction of various defense-related genes with mycorrhizal colonization [99]. It was shown that addition of arbuscular mycorrhizal fungi and Pseudomonas fluorescens to the soil can reduce the development of root-rot disease and enhance the yield of Phaseolus vulgaris L. [100].

\section{Mechanism of action of various biofertilizers}

Mycorrhiza is the association of fungus with the roots of higher plants. While it remains an enigma, it serves as a model system to understand the mechanism behind stimulation of growth in the root cells as a result of mycorrhizal inhabitation. Genome sequencing of two EM fungi (ectomycorrhizae), the L. bicolor 13 , and $T$. melanosporum (black truffle) 14, helps in the identification of factors that regulate the development of mycorrhiza and its function in the plant cell [101]. Fifteen genes that up-regulated during symbiosis were identified as putative hexose transporters in L. bicolor. Its genome lacked genes encoding invertases making it dependent on plants for glucose. However, melanosporum possesses one invertase gene, and unlike L. bicolor it can directly use the sucrose of the host [101]. The up-regulation of transporter genes during symbiosis indicated the action of transportation of useful compounds like amino acids, oligopeptides and polyamines through the symbiotic interface from one organism to other. Free living mycelium can take nitrate and ammonium from the soil. Subsequently, these compounds reach the mantle and hartig net and are then transferred to the plants. Cysteine-rich proteins (MISSP7) of fungus play an important role as effectors and facilitators in the formation of symbiotic interfaces [102]. Many genes related to auxin biosynthesis and root morphogenesis showed up-regulation during mycorrhizal colonization $[69,103,104]$. Further, G. versiforme possesses inorganic phosphate (Pi) transporters on its hyphae which help in the direct absorption of phosphate from the soil and a glutamine synthase gene was found in G. intraradice, which strengthens the possibility of nitrogen metabolism in fungal hyphe that can be transported later to the plant [105]. Bioactive compounds called Myc factors similar to Nod factors of Rhizobium are suggested to be secreted by mycorrhiza and Rhizobium and perceived by host roots for the activation of signal transduction pathway or common symbiosis (SYM) pathway [106,107]. The pathways that prepare plant for both AM and Rhizobium infection have some common points. The common SYM pathway prepares the host plant to bring about changes at the molecular and anatomical level with the first contact of fungal hyphae. So far, calcium is supposed to be the hub of secondary messengers via $\mathrm{Ca}^{2+}$ spiking in the nuclear region of root hairs [108]. Rhizobium leguminosarum biovar viciae can induce various genes in the plants like pea, alfalfa and sugar beet as evident from the microarray studies [40]. PGPR produce IAA which, in turn, induces the production of nitric Oxide (NO), which acts as a second messenger to trigger a complex signaling network leading to improved root growth and developmental processes [109].

Expression of ENOD11 and many defense-related genes and root remodelling genes get up-regulated during entry. Subsequently, this allows the formation of a pre-penetration apparatus or PPA [110]. Though the biology behind the development of arbuscules is unknown, a gene called vapyrin when knocked down causes a decline in the growth of arbuscules [111]. Many other genes including subtilisin protease 65, phosphate transporter 66 or two $\mathrm{ABC}$ transporters 67 are known to be involved in arbuscules formation [112,113]. Nitrogenfixation genes are popularly used by scientists today to create engineered plants that can fix atmospheric nitrogen. The induction of nif genes in case of nitrogen fixing bacteria takes place under low concentration of nitrogen and oxygen in the rhizosphere [1]. Interestingly, sugarcane plantlets inoculated with a wild strain of G. diazotrophicus, have demonstrated fixation of radioactive $\mathrm{N}_{2}$ when compared with the G. diazotrophicus mutant that has mutant nif $\mathrm{D}$ gene which proved the significance of nif genes. Efficiency of nitrogen fixation is dependent on the utilization of carbon $[114,115]$. A bacterium like $\mathrm{Ba}$ cillus subtilis (UFLA285) can differentially induce 247 genes in cotton plant as compared to control where no PGPR was supplied to the cotton plant [85]. Many disease resistance genes that work via jasmonate/ethylene signaling as well as osmotic regulation via proline synthesis genes were differentially expressed with UFLA285 induction [85]. Various differentially expressed genes 
were identified which include metallothionein-like protein type 1, a NOD26-like membrane integral protein, ZmNIP2-1, a thionin family protein, an oryzain gamma chain precursor, stress-associated protein 1 (OsISAP1), probenazole-inducible protein PBZ1 and auxin and ethylene-responsive genes [116]. The expression of the defense-related proteins PBZ1 and thionins were found to get repressed in the rice- $\mathrm{H}$ seropedicae association, suggesting the modulation of plant defense responses during colonisation [116].

Among the PGPR species, Azospirillum was suggested to secrete gibberellins, ethylene and auxins [117]. Some plant associated bacteria can also induce phytohormone synthesis, for example lodgepole pine when inoculated with Paenibacillus polymyxa had elevated levels of IAA in the roots [118]. Rhizobium and Bacillus were found to synthesize IAA at different cultural conditions such as $\mathrm{pH}$, temperature and in the presence of agro waste as substrate [119]. Ethylene, unlike other phytohormones, is responsible for the inhibition of growth of dicot plants [69]. It was found by Glick et al. [120] that PGPR could enhance the growth of plant by suppressing the expression of ethylene. Interestingly, a model was suggested in which it was shown that ethylene synthesis from 1aminocyclopropane-1-carboxylate (ACC), an immediate precursor of ethylene, which is hydrolyzed by bacterial ACC-deaminase enzyme in the need of nitrogen and carbon source is also one of the mechanisms of induction of conditions suitable for growth. ACC-deaminase activity was also found in the bacteria such as Alcaligenes sp., Bacillus pumilus, Pseudomonas sp. and Variovorax paradoxus [69]. The involvement of ACC deaminase in the indirect influence on the growth of plants was proved in Canola, where mutations in ACC deaminase gene caused the loss of effect of growth promoting Pseudomonas putida [29]. Interestingly, the potential of PGPRs was further enhanced by introducing genes involved in the direct oxidation (DO) pathway and

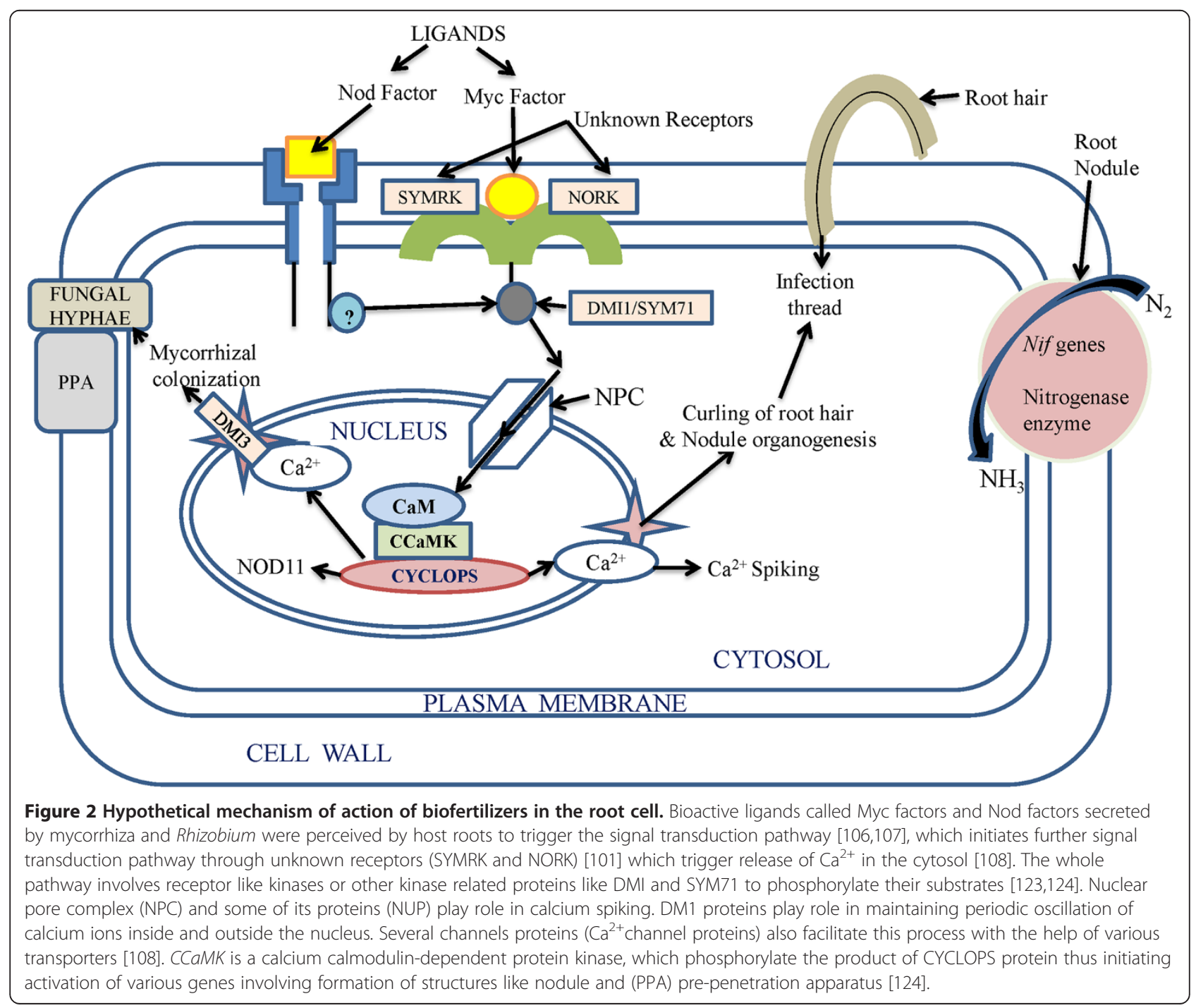


mineral phosphate solubilisation (MPS) into some useful strains of PGPRs. Gene encoding glucose dehydrogenase (gcd) involved in the DO pathway was cloned and characterized from Acinetobacter calcoaceticus and E. coli and Enterobacter asburiae [121]. Also a soluble form of gcd has been cloned from Acinetobacter calcoaceticus and G. oxydans [122]. Furthermore there are reports of sitedirected mutagenesis of glucose dehydrogenase (GDH) and gluconate dehydrogenase (GADH) that has improved the activity of this enzyme. Mere substitution of S771M provided thermal stability to E.coli while mutation of glutamate 742 to lysine improved the EDTA tolerance of $E$. coli PQQGDH. The application of this technology was achieved by transferring genes involved in the DO pathway viz., GDH, GADH and pyrroloquinoline quinine $(P Q Q)$ to rhizobacteria, and phosphoenolpyruvate carboxylase $(P P C)$ to $P$. Fluorescens, provide the MPS trait [122] (Figure 2).

\section{Conclusions}

Environmental stresses are becoming a major problem and productivity is declining at an unprecedented rate. Our dependence on chemical fertilisers and pesticides has encouraged the thriving of industries that are producing life-threatening chemicals and which are not only hazardous for human consumption but can also disturb the ecological balance. Biofertilizers can help solve the problem of feeding an increasing global population at a time when agriculture is facing various environmental stresses. It is important to realise the useful aspects of biofertilizers and implement its application to modern agricultural practices. The new technology developed using the powerful tool of molecular biotechnology can enhance the biological pathways of production of phytohormones. If identified and transferred to the useful PGPRs, these technologies can help provide relief from environmental stresses. However, the lack of awareness regarding improved protocols of biofertiliser applications to the field is one of the few reasons why many useful PGPRs are still beyond the knowledge of ecologists and agriculturists. Nevertheless, the recent progresses in technologies related to microbial science, plant-pathogen interactions and genomics will help to optimize the required protocols. The success of the science related to biofertilizers depends on inventions of innovative strategies related to the functions of PGPRs and their proper application to the field of agriculture. The major challenge in this area of research lies in the fact that along with the identification of various strains of PGPRs and its properties it is essential to dissect the actual mechanism of functioning of PGPRs for their efficacy toward exploitation in sustainable agriculture.

Competing interests

Authors declare that they have no competing interests.

\section{Authors' contributions}

MWA and DB contributed with the paper writing, data researching and designs the Figures. RKS supported the paper writing, data researching and revised the changes made to this paper. NT approved the changes made, and also with data researching and formatted the review. All authors read and approved the final manuscript.

\section{Acknowledgments}

Work on biofertilizers, signal transduction and plant stress tolerance in NT's laboratory is partially supported by ICGEB, New Delhi, Department of Science and Technology (DST) and Department of Biotechnology (DBT), Government of India.

Received: 25 February 2014 Accepted: 30 April 2014

Published: 8 May 2014

\section{References}

1. Santos VB, Araujo SF, Leite LF, Nunes LA, Melo JW: Soil microbial biomass and organic matter fractions during transition from conventional to organic farming systems. Geoderma 2012, 170:227-231.

2. Youssef MMA, Eissa MFM: Biofertilizers and their role in management of plant parasitic nematodes. A review. E3 J Biotechnol. Pharm Res 2014, 5:1-6.

3. Raja N: Biopesticides and biofertilizers: ecofriendly sources for sustainable agriculture. J Biofertil Biopestici 2013, 1000e112:1000e112.

4. Araujo ASF, Santos VB, Monteiro RTR: Responses of soil microbial biomass and activity for practices of organic and conventional farming systems in Piauistate, Brazil. Eur J Soil Biol 2008, 44:225-230.

5. Megali L, Glauser G, Rasmann S: Fertilization with beneficial microorganisms decreases tomato defenses against insect pests. Agron Sustain Dev 2013, doi:10.1007/s13593-013-0187-0.

6. Sahoo RK, Ansari MW, Pradhan M, Dangar TK, Mohanty S, Tuteja N: Phenotypic and molecular characterization of efficient native Azospirillum strains from rice fields for crop improvement. Protoplasma 2014, doi:10.1007/s00709-013-0607-7.

7. Sinha RK, Valani D, Chauhan K, Agarwal S: Embarking on a second green revolution for sustainable agriculture by vermiculture biotechnology using earthworms: reviving the dreams of Sir Charles Darwin. Int J Agric Health Saf 2014, 1:50-64.

8. Singh JS, Pandey VC, Singh DP: Efficient soil microorganisms: a new dimension for sustainable agriculture andenvironmental development. Agric Ecosyst Environ 2011, 140:339-353.

9. Adesemoye AO, Kloepper JW: Plant-microbes interactions in enhanced fertilizer-use efficiency. Appl Microbiol Biotechnol 2009, 85:1-12.

10. Adesemoye $\mathrm{AO}$, Torbert HA, Kloepper JW: Plant growth-promoting rhizobacteria allow reduced application rates of chemical fertilizers. Micro Ecol 2009, 58:921-929.

11. Egamberdieva D, Kamilova F, Validov S, Gafurova L, Kucharova Z, Lugtenberg B: High incidence of plant growth stimulating bacteria associated with the rhizosphere of wheat grown on salinated soil in Uzbekistan. Environ Microbiol 2008, 10:1-9.

12. Mendes R, Garbeva P, Raaijmakers JM: The rhizosphere microbiome: significance of plant beneficial plant pathogenic and human pathogenic microorganisms. FEMS Microbiol Rev 2013, 37:634-663.

13. Bulgarelli D, Schlaeppi K, Spaepen S, Loren V, van Themaat E, Schulze-Lefert $P$ : Structure and functions of the bacterial microbiota of plants. Annu Rev Plant Biol 2013, 64:807-838.

14. Berg G, Zachow C, Müller H, Phillips J, Tilcher R: Next-generation bio-products sowing the seeds of success for sustainable agriculture. Agronomy 2013, 3:648-656

15. Hirsch PR, Mauchline TH: Who's who in the plant root microbiome? Nat Biotechnol 2012, 30:961-962.

16. Gopal M, Gupta A, Thomas GV: Bespoke microbiome therapy to manage plant diseases. Front Microbiol 2013, 5:15.

17. Nina K, Thomas WK, Prem SB: Beneficial organisms for nutrient uptake. VFRC report 2014/1, virtual fertilizer research center. Washington, DC: Wageningen Academic Publishers: 2014:63.

18. Sahoo RK, Ansari MW, Dangar TK, Mohanty S, Tuteja N: Phenotypic and molecular characterization of efficient nitrogen fixing Azotobacter strains of the rice fields. Protoplasma 2013, doi:10.1007/s00709-013-0547-2. 
19. Sahoo RK, Bhardwaj D, Tuteja N: Biofertilizers: a sustainable eco-friendly agricultural approach to crop improvement. In Plant Acclimation to Environmental Stress. Edited by Tuteja N, Gill SS. LLC 233 Spring Street, New York, 10013, USA: Springer Science plus Business Media; 2013b:403-432.

20. Dogan K, Kamail Celik I, Mustafa Gok M, Ali C: Effect of different soil tillage methods on rhizobial nodulation, biyomas and nitrogen content of second crop soybean. Afr J Microbiol Res 2011, 5:3186-3194.

21. Aziz G, Bajsa N, Haghjou T, Taule C, Valverde A, Mariano J, Arias A: Abundance, diversity and prospecting of culturable phosphate solubilizing bacteria on soils under crop-pasture rotations in a no-tillage regime in Uruguay. App/ Soil Ecol 2012, 61:320-326.

22. Dhanasekar $R$, Dhandapani R: Effect of biofertilizers on the growth of Helianthus annuus. Int J plant, Ani Environ Sci 2012, 2:143-147.

23. Choudhury MA, Kennedy IR: Prospects and potentials for system of biological nitrogen fixation in sustainable rice production. Biol Fertil Soils 2004, 39:219-227.

24. Revillas JJ, Rodelas B, Pozo C, Martinez-Toledo MV, Gonzalez L: Production of B-Group vitamins by two Azotobacter strainswith phenolic compounds as sole carbon source under diazotrophicand adiazotrophic conditions. J Appl Microbiol 2000, 89:486-493.

25. Abd El-Fattah DA, Ewedab WE, Zayed MS, Hassaneina MK: Effect of carrier materials, sterilization method, and storage temperature on survival and biological activities of Azotobacter chroococcum inoculants. Ann Agric Sci 2013, 58:111-118.

26. Gholami A, Shahsavani S, Nezarat S: The Effect of Plant Growth Promoting Rhizobacteria (PGPR) on Germination seedling Growth and Yield of Maize. Int J Biol Life Sci 2009, 5:1.

27. Mali GV, Bodhankar MG: Antifungal and phytohormone production potential of Azotobacter chroococcum isolates from Groundnut (Arachis hypogea L.) rhizosphere. Asian J Exp Sci 2009, 23:293-297.

28. Wani SA, Chand S, Ali T: Potential use of Azotobacter chroococcum in crop production: an overview. Curr Agric Res J 2013, 1:35-38.

29. Bhattacharyya PN, Jha DK: Plant growth-promoting rhizobacteria (PGPR): emergence in agriculture. World J Microbiol Biotechnol 2012, 28:1327-1350.

30. Saikia SP, Bora D, Goswami A, Mudoi KD, Gogoi A: A review on the role of Azospirillum in the yield improvement of non leguminous crops. Afr J Microbiol Res 2013, 6:1085-1102.

31. Bashan $Y$, Holguin G, Bashan LE: Azospirillum-plant relationships: agricultural, physiological, molecular and environmental advances (1997-2003). Can J Microbiol 2004, 50:521-577.

32. Mehdipour-Moghaddam MJ, Emtiazi G, Salehi Z: Enhanced auxin production by Azospirillum pure cultures from plant root exudates. J Agr Sci Tech 2012, 14:985-994.

33. Sarig S, Blum A, Okon Y: Improvement of the water status and yield of field-grown grain sorghum (Sorghum bicolor) by inoculation with Azospirillum brasilense. J Agric Sci 1992, 110:271-277.

34. Ilyas N, Bano A, lqbal S, Raja NI: Physiological, biochemical and molecular characterization of Azospirillum spp. isolated from maize under water stress. Pak J Bot 2012, 44:71-80.

35. Askary M, Mostajeran A, Amooaghaei R, Mostajeran M: Influence of the co-inoculation Azospirillum brasilense and Rhizobium meliloti plus 2,4-D on grain yield and N, P, K content of Triticum aestivum (cv. Baccros and Mahdavi). Am Eurasian J Agric Environ Sci 2009, 5:296-307.

36. Sharma P, Sardana V, Kandola SS: Response of groundnut (Arachishypogaea L.) to Rhizobium Inoculation. Libyan Agric Res Centre J Int 2011, 2:101-104.

37. Nehra K, Yadav SA, Sehrawat AR, Vashishat RK: Characterization of heat resistant mutant strains of Rhizobium sp. [Cajanus] for growth, survival and symbiotic properties. Indian J Microbiol 2007, 47:329-335.

38. Patil PL, Medhane NS: Seed inoculation studies in gram (Cicer arietinum) with different strains of Rhizobium sp. Plant Soil 1974, 40:221-223.

39. Rashid MH, Schafer H, Gonzalez J, Wink M: Genetic diversity of rhizobia nodulating lentil (Lens culinaris) in Bangladesh. Syst Appl Microbiol 2012, 35:98-109.

40. Ramachandran VK, East AK, Karunakaran R, Downie JA, Poole SP: Adaptation of Rhizobium leguminosarum to pea, alfalfa and sugar beet rhizosphere investigated by comparative transcriptomics. Genome Biol 2011, 12:106-109.

41. Hussain N, Mujeeb F, Tahir M, Khan GD, Hassan NM, Bari A: Effectiveness of Rhizobium under salinity stress. Asian J Plant Sci 2002, 1:12-14.

42. Grossman JM, Schipanski ME, Sooksanguan T, Drinkwater LE: Diversity of rhizobia nodulating soybean Glycine max (Vinton)] varies under organic and conventional management. App/ Soil Ecol 2011, 50:14-20.
43. Peng G, Yuan Q, Li H, Zhang W, Tan Z: Rhizobium oryzae sp. nov., isolated from the wild rice Oryza alta. Int J Syst Evol Microbiol 2008, 58:2158-2163.

44. Chi F, Yang P, Han F, Jing Y, Shen S: Proteomic analysis of rice seedlings infected by Sinorhizobium meliloti 1021. Proteomics 2010, 10:1861-1874.

45. Thamer S, Schädler M, Bonte D, Ballhorn DJ: Dual benefit from a belowground symbiosis: nitrogen fixing rhizobia promote growth and defense against a specialist herbivore in a cyanogenic plant. Plant Soil 2011, 34:1209-1219.

46. Menjivar RD, Cabrera JA, Kranz J, Sikora RA: Induction of metabolite organic compounds by mutualistic endophytic fungi to reduce the greenhouse whitefly Trialeurodes vaporariorum (Westwood) infection on tomato. Plant Soil 2012, 352:233-241.

47. Pindi PK, Satyanarayana SDV: Liquid microbial consortium- a potential tool for sustainable soil health. J Biofertil Biopest 2012, 3:4.

48. Dastager SG, Deepa CK, Pandey A: Isolation and characterization of novel plant growth promoting Micrococcus sp NII-0909 and its interaction with cowpea. Plant Physiol Biochem 2010, 48:987-992.

49. Ogbo FC: Conversion of cassava wastes for biofertilizer production using phosphate solubilizing fungi. Bioresour Technol 2010, 101:4120-4124

50. Park J, Bolan N, Megharaj M, Naidu R: Isolation of Phosphate-Solubilizing Bacteria and characterization of their Effects on Lead Immobilization. Pedologist 2010, 53:67-75.

51. Ambrosini A, Beneduzi A, Stefanski T, Pinheiro F, Vargas L, Passaglia L: Screening of plant growth promoting Rhizobacteria isolated from sunflower Helianthus annuus L. Plant \& Soil 2012, 356:245-264.

52. Mohammadi K, Yousef Sohrabi Y: Bacterial Biofertilizers for sustainable crop production: A review. J Agric Biol Sci 2012, 7:307-316.

53. Kogel KH, Franken $P$, Huckelhovenl R: Endophyte or parasite - what decides? Curr Opin Plant Biol 2006, 9:358-363.

54. Lamabam PS, Gill SS, Tuteja N: Unraveling the role of fungal symbionts in plant abiotic stress tolerance. Plant Signal Behav 2011, 6:175-191.

55. Smith S, Lakobsen I, Gronlund M, Smith FA: Roles of arbuscular mycorrhizas in plant phosphorus nutrition: interactions between pathways of phosphorus uptake in arbuscular mycorrhizal roots have important implications for understanding and manipulating plant phosphorus acquisition. Plant Physiol 2011, 156:1050-1057.

56. Abdel-Lateif $K$, Bogusz D, Hocher V: The role of flavonoids in the establishment of plant roots endosymbioses with arbuscular mycorrhiza fungi, rhizobia and Frankia bacteria. Plant Signal Behav 2012, 7:636-641.

57. Roy M, Srivastava RC: Assembling BNF system in rice plant: frontier areas of research. Curr Sci 2013, 104:3-10.

58. Venkataraman GS, Neelakantan S: Effect of cellular constituents of the nitrogen fixing blue-green algae. Cylindrospermum nusciola on the root growth of rice seedlings. J General Appl Microbio/ 1967, 13:53-61.

59. Pandey S, Shrivastava AK, Rai R, Rai LC: Molecular characterization of Alr1105 a novel arsenate reductase of the diazotrophic cyanobacterium Anabaena sp. PCC7120 and decoding its role in abiotic stress management in Escherichia coli. Plant Mol Biol 2013, 83:417-432.

60. Chaurasia AK, Apte SK: Improved eco-friendly recombinant Anabaena sp. strain PCC7120 with enhanced nitrogen biofertilizer potential. Appl Environ Microbiol 2011, 77:395-399.

61. Yang JW, Kloepper JW, Ryu CM: Rhizosphere bacteria help plants tolerate abiotic stress. Trends Plant Sci 2009, 14:1-4.

62. Antoun H, Prevost D: Ecology of plant growth promoting rhizobacteria. In PGPR: Biocontrol and Biofertilization. Edited by Siddiqui ZA. Dordrecht: Springer; 2005:1-38.

63. Pandey PK, Yadav SK, Singh A, Sarma BK, Mishra A, Singh HB: Cross-Species Alleviation of Biotic and Abiotic Stresses by the Endophyte Pseudomonas aeruginosa PW09. J Phytopathol 2012, 160:532-539.

64. Paul D, Nair S: Stress adaptations in a plant growth promoting Rhizobacterium (PGPR) with increasing salinity in the coastal agricultural soils. J Basic Microbiol 2008, 48:1-7.

65. Yao L, Wu Z, Zheng Y, Kaleem I, Li C: Growth promotion and protection against salt stress by Pseudomonas putida Rs-198 on cotton. European $J$ Soil Biol 2010, 46:49-54.

66. Schnider-Keel U, Seematter A, Maurhofer M, Blumer C, Duffy B, Gigot-Bonnefoy C, Reimmann C, Notz R, Defago G, Haas D, Keel C: Autoinduction of 2,4-diacetylphloroglucinol biosynthesis in the biocontrol agent Pseudomonas fluorescens $\mathrm{CHAO}$ and repression by the bacterial metabolites salicylate and pyoluteorin. J Bacterio/ 2000, 182:1215-1225. 
67. Weller DM, Mavrodi DV, van Pelt JA, Pieterse CM, van Loon LC, Bakker PA: Induced systemic resistance in Arabidopsis thaliana against Pseudomonas syringae pv. tomato by 2,4-diacetylphloroglucinol-producing Pseudomonas fluorescens. Phytopathology 2012, 102:403-412.

68. Egamberdiyeva D: The effect of plant growth promoting bacteria on growth and nutrient uptake of maize in two different soils. Appl. Soil Ecol 2007, 36:184-189.

69. Ansari MW, Trivedi DK, Sahoo RK, Gill SS, Tuteja N: A critical review on fungi mediated plant responses with special emphasis to Piriformospora indica on improved production and protection of crops. Plant Physiol Biochem 2013, 70:403-410.

70. Alavi P, Starcher MR, Zachow C, Müller H, Berg G: Root-microbe systems: the effect and mode of interaction of stress protecting agent (SPA) Stenotrophomonas rhizophila DSM14405 ${ }^{\top}$. Front Plant Sci 2013, 4:141.

71. Kohler J, Caravaca F: An AM fungus and a PGPR intensify the adverse effects of salinity on the stability of rhizosphere soil aggregates of Lactuca sativa Roldan. Soil Biol Biochem 2010, 42:429-434.

72. Gao X, Lu X, Wu M, Zhang H, Pan R, Tian J, Li S, Liao H: Co-Inoculation with Rhizobia and AMF Inhibited Soybean Red Crown Rot: From Field Study to Plant Defense-Related Gene Expression Analysis. PLOS ONE 2012, 7:e33977. doi:10.1371/journal.pone.0033977.

73. Aliasgharzad N, Reza M, Neyshabouri Salimi G: Effects of arbuscular mycorrhizal fungi and Bradyrhizobium japonicum on drought stress of soybean. Biologia 2006, 19:324-328.

74. German MA, Burdman S, Okon Y, Kigel J: Effects of Azospirillum brasilense on root morphology of common bean (Phaseolus vulgaris L.) under different water regimes. Biol Fertil Soils 2000, 32:259-264.

75. Casanovas EM, Barassi CA, Sueldo RJ: Azospirillum inoculation mitigates water stress effects in maize seedlings. Cer Res Commun 2002, 30:343-350.

76. Creus CM, Graziano M, Casanovas EM, Pereyra MA, Simontacchi M, Puntarulo S: Nitric oxide is involved in the Azospirillum brasilense-induced lateral root formation in tomato. Planta 2005, 221:297-303.

77. Joe MM, Jaleel CA, Sivakumar PK, Zhao CX, Karthikeyan B: Co-aggregation in Azospirillum brasilensense MTCC-125 with other PGPR strains: Effect of physical and chemical factors and stress endurance ability. J Taiwan Inst Chem Engg 2009, 40:491-499.

78. Marulanda A, Barea JM, Azcon R: Stimulation of Plant Growth and Drought Tolerance by Native Microorganisms (AM Fungi and Bacteria) from Dry Environments: Mechanisms Related to Bacterial Effectiveness. J Plant Growth Regul 2009, 28:115-124.

79. Heidari M, Golpayegani A: Effects of water stress and inoculation with plant growth promoting rhizobacteria (PGPR) on antioxidant status and photosynthetic pigments in basil (Ocimum basilicum L.). J Saudi Soc Agric Sci 2012, 11:57-61.

80. Liddycoat SM, Greenberg BM, Wolyn DJ: The effect of plant growthpromoting rhizobacteria on asparagus seedlings and germinating seeds subjected to water stress under greenhouse conditions. Can J Microbiol 2009, 55:388-394.

81. Ruiz-Sanchez M, Aroca R, Munoz Y, Polon R, Ruiz-Lozano JM: The arbuscular mycorrhizal symbiosis enhances the photosynthetic efficiency and the antioxidative response of rice plants subjected to drought stress. J Plant Physiol 2010, 167:862-869.

82. Aroca R, Ruiz-Lozano JM, Zamarreno AM, Paz JA, García-Mina JM, Pozo MJ, Lopez-Raez JA: Arbuscular mycorrhizal symbiosis influences strigolactone production under salinity and alleviates salt stress in lettuce plants. J Plant Physiol 2013, 170:47-55

83. Gill SS, Khan NA, Tuteja N: Cadmium at high dose perturbs growth, photosynthesis and nitrogen metabolism while at low dose it up regulates sulfur assimilation and antioxidant machinery in garden cress ( Lepidium sativum L.). Plant Sci 2012, 182:112-120.

84. Samuel S, Muthukkaruppan SM: Characterization of plant growth promoting rhizobacteria and fungi associated with rice, mangrove and effluent contaminated soil. Curr Bot 2011, 2:22-25.

85. Baharlouei K, Pazira E, Solhi M: Evaluation of Inoculation of plant Growth-Promoting Rhizobacteria on Cadmium. Singapore: International Conference on Environmental Science and Technology IPCBEE vol.6 IACSIT Press; 2011.

86. Tang J, Wang R, Niu X, Wang M, Zhou Q: Characterization on the rhizoremediation of petroleum contaminated soil as affected by different influencing factors. Biogeosciences Discuss 2010, 7:4665-4688.
87. Murphy JF, Zehnder GW, Schuster DJ, Sikora EJ, Polstan JE, Kloepper JW: Plant growth promoting rhizobacteria mediated protection in tomato against tomato mottle virus. Plant Dis 2000, 84:79-84.

88. Backman PA, Sikora RA: Endophytes: an emerging tool for biological control. Biol Control 2008, 46:1-3.

89. Ryu CM, Farag MA, Hu CH, Reddy MS, Kloepper JW, Pare PW: Bacterial volatiles induce systemic resistance in Arabidopsis. Plant Physiol 2004, 134:1017-1026.

90. Murphy JF, Reddy MS, Ryu CM, Kloepper JW, Li R: Rhizobacteria mediated growth promotion of tomato leads to protection against cucumber mosaic virus. Phytopathology 2003, 93:1301-1307.

91. Aravind R, Kumar A, Eapen SJ, Ramana KV: Endophytic bacterial flora in root and stem tissues of black pepper (Piper nigrum L.) genotype: isolation, identification and evaluation against Phytophthora capsici. Lett Appl Microbiol 2009, 48:58-64.

92. Zhang N, Kai W, He X, Li S, Zhang Z, Shen B, Yang X, Zhang R, Huang Q, Shen $\mathrm{Q}$ : A new bioorganic fertilizer can effectively control banana wilt by strong colonization with Bacillus subtilis N11. Plant Soil 2011, 344:87-97.

93. Medeiros FHV, Souza RM, Medeiros FCL, Zhang H, Wheeler T, Payton P, Ferro HM, Paré PW: Transcriptional profiling in cotton associated with Bacillus subtilis (UFLA285) induced biotic-stress tolerance. Plant Soil 2011, 347:327-337.

94. Ling N, Huang Q, Guo S, Shen Q: Paenibacillus polymyxa SQR-21 systemically affects root exudates of watermelon to decrease the conidial germination of Fusarium oxysporum f.sp. niveum. Plant Soil 2011, 341:485-493.

95. Harish S, Kavino M, Kumar N, Balasubramanian P, Samiyappan R: Induction of defense-related proteins by mixtures of plant growth promoting endophytic bacteria against Banana bunchy top virus. Biol Control 2009, 51:16-25.

96. Khalil S, Labuschagne I: Role of mycorrhizae, pathogens and weeds in sustainable pine Forest management Soil biology and biochemistry section, national agricultural research centre, Islamabad-Pakistan. Int J Agric Biol 2002, 4:1.

97. Riedlinger J, Schrey SD, Tarkka MT, Hampp R, Kapur M, Fiedler HP: Auxofuran, a novel substance stimulating growth of fly agaric, produced by the mycorrhiza helper bacterium Streptomyces AcH 505. Appl Environ Microbiol 2006, 72:3550-3557.

98. Toussaint JP, Kraml M, Nell M, Smith SE, Smith FA, Steinkellner S, Schmiderer H, Novak V: Effect of Glomus mosseae on concentrations of rosmarinic and caffeic acids and essential oil compounds in basil inoculated with Fusarium oxysporum f. sp. basilica. Plant Pathol 2008, 57:1109-1116.

99. Liu JY, Maldonado-Mendoza I, Lopez-Meyer M, Cheung F, Town CD, Harrison MJ: Arbuscular mycorrhizal symbiosis is accompanied by local and systemic alterations in gene expression and an increase in disease resistance in the shoots. Plant J 2007, 50:529-544.

100. Neeraj KS: Organic amendments to soil inoculated arbuscular mycorrhizal fungi and Pseudomonas fluorescens treatments reduce the development of root-rot disease and enhance the yield of Phaseolus vulgaris L. Eur J Soil Biol 2011, 47:288-295.

101. Bonfante P, Genre A: Mechanisms underlying beneficial plant-fungus interactions in mycorrhizal symbiosis. Nat Commun 2010, 27:1-48.

102. Plett JM, Kemppainen M, Kale SD, Kohler A, Leque V, Brun A, Tyler BM, Pardo AG, Martin F: A secreted effector protein of Laccaria bicolor is required for symbiosis development. Curr Biol 2011, 21:1197-1203.

103. Splivallo R, Fischer U, Gobel C, Feussner I, Karlovsky P: Truffles regulate plant root morphogenesis via the production of auxin and ethylene. Plant Physiol 2009, 150:2018-2029.

104. Abdel-Raouf N, Al-Homaidan AA, Ibraheem IBM: Agricultural importance of algae. Afr J Biotechnol 2012, 11:11648-11658.

105. Salvioli A, Zouari I, Chalot M, Bonfante P: The arbuscular mycorrhizal status has an impact on the transcriptome profile and amino acid composition of tomato fruit. BMC Plant Biol 2012, 12:44.

106. Kosuta S: Diffusible factor from arbuscular mycorrhizal fungi induces symbiosis-specific expression in roots of Medicago truncatula. Plant Physiol 2003, 131:952-962.

107. Roberts NJ, Morieri G, Kalsi G, Rose A, Stiller J, Edwards A, Xie F, Gresshoff PM, Oldroyd GE, Downie JA, Etzler ME: Rhizobial and mycorrhizal symbioses in Lotus japonicus require lectin nucleotide phosphohydrolase, which acts upstream of calcium signaling. Plant Physiol 2013, 161:556-567.

108. Sieberer BJ, Chabaud M, Timmers AC, Monin A, Fournier J, Barker DG: A nuclear-targeted cameleon demonstrates intranuclear $\mathrm{Ca}^{2+}$ spiking in 
Medicago truncatula root hairs in response to rhizobial nodulation factors. Plant Physiol 2009, 151:1197-1206.

109. Molina-Favero C, Mónica Creus C, Luciana Lanteri M, Correa-Aragunde N, Lombardo MC, Barassi AC, Lamattina L: Nitric Oxide and Plant Growth Promoting Rhizobacteria: Common Features Influencing Root Growth and Development. Adv Bot Res 2007, 46:1-33.

110. Bucher $M$, Wegmüller $S$, Drissner D: Chasing the structures of small molecules in arbuscular mycorrhizal signalling. Curr Opin Plant Biol 2009, 12:500-507.

111. Bapaume L, Reinhardt D: How membranes shape plant symbioses: signaling and transport in nodulation and arbuscular mycorrhiza. Front Plant Sci 2012, 3:223.

112. Zhang Q, Blaylock LA, Harrison MJ: Two Medicago truncatula Half-ABC transporters are essential for arbuscule development in arbuscular mycorrhizal symbiosis. Plant Cell 2010, 22:1483-1497.

113. Tromas A, Parizot B, Diagne N, Champion A, Hocher V: Heart of endosymbioses: transcriptomics reveals a conserved genetic program among arbuscular mycorrhizal, actinorhizal and legume-rhizobial symbioses. PLOS ONE 2012, 7:e44742.

114. Sevilla M, Burris RH, Gunapala N, Kennedy C: Comparison of benefit to sugarcane plant growth and $15 \mathrm{n} 2$ incorporation following inoculation of sterile plants with Acetobacter diazotrophicus wild-type and Nif-mutant strains. Mol Plant-Microbe Interact 2001, 14:358-366.

115. Bertalan M, Albano R, de-Pádua V, Rouws L, Rojas C, Hemerly A, Teixeira $K$, Schwab S, Araujo J, Oliveira A, França L, Magalhães V, Alquéres S, Cardoso A, Almeida W, Loureiro MM, Nogueira E, Cidade D, Oliveira D, Simão T, Macedo J, Valadão A, Dreschse M, Freitas F, Vida M, Guedes H, Rodrigues E, Meneses C, Brioso P, Pozzer $L$, et al: Complete genome sequence of the sugarcane nitrogen-fixing endophyte Gluconacetobacter diazotrophicus Pal5. BMC Genomics 2009, 10:450.

116. Brusamarello-Santos L, Pacheco F, Aljanabi S, Monteiro R, Cruz L, Baura V, Pedrosa F, Souza E, Wassem R: Differential gene expression of rice roots inoculated with the diazotroph Herbaspirillum seropedicae. Plant Soil 2012, 356:113-125.

117. Perrig D, Boiero ML, Masciarelli OA, Penna C, Ruiz OA, Cassan FD, Luna MV: Plant-growth promoting compounds produced by two agronomically important strains of Azospirillum brasilense, and implications for inoculant formulation. Appl Microbiol Biotechnol 2007, 75:1143-1150.

118. Bent E, Tuzun S, Chanway CP, Enebak S: Alterations in plant growth and in root hormone levels of lodgepole pines inoculated with rhizobacteria. Can J Microbiol 2001, 47:793-800.

119. Sudha M, Gowri RS, Prabhavati P, Astapriya P, Devi SY, Saranya A: Production and optimization of indole-acetic-acid by indigenous micro flora using agro waste as substrate. Pakistan J Biological Sci 2012, 15:39-43.

120. Glick BR, Penrose DM, Li J: A model for the lowering of plant ethylene concentrations by plant growth-promoting bacteria. J Theor Biol 1998, 190:63-68.

121. Tripura CB, Sudhakar Reddy P, Reddy MK, Sashidhar B, Podile AR: Glucose dehydrogenase of a rhizobacterial strain of Enterobacter asburiae involved in mineral phosphate solubilization shares properties and sequence homology with other members of enterobacteriaceae. Indian J Microbiol 2007, 47:126-131.

122. Sashidhar B, Podile AR: Mineral phosphate solubilisation by rhizosphere bacteria and scope for manipulation of the direct oxidation pathway involving glucose dehydrogenase. J Appl Microbiol 2010, 109:1-12.

123. Ané JM1, Kiss GB, Riely BK, Penmetsa RV, Oldroyd GE, Ayax C, Lévy J, Debellé F, Baek JM, Kalo P, Rosenberg C, Roe BA, Long SR, Dénarié J, Cook DR: Medicago truncatula DMI1required for bacterial and fungal symbioses in legumes. Sci 2004, 303:1364-1367.

124. Maillet $F$, Poinsot V, André O, Puech-Pagès V, Haouy A, Gueunier M, Cromer L, Giraudet D, Formey D, Niebel A, Martinez EA, Driguez H, Bécard G, Dénarié J: Fungal lipochitooligosaccharide symbiotic signals in arbuscular mycorrhiza. Nature 2011, 469:58-63.

\section{doi:10.1186/1475-2859-13-66}

Cite this article as: Bhardwaj et al: Biofertilizers function as key player in sustainable agriculture by improving soil fertility, plant tolerance and crop productivity. Microbial Cell Factories 2014 13:66. 